\title{
Porcine Circoviruses and Xenotransplantation
}

\author{
Joachim Denner * and Annette Mankertz \\ Robert Koch Institute, Nordufer 20, 13353 Berlin, Germany; MankertzA@rki.de \\ * Correspondence: DennerJ@rki.de; Tel.: +49-30-18754-2800 \\ Academic Editors: Linda Dixon and Simon Graham \\ Received: 1 March 2017; Accepted: 12 April 2017; Published: 20 April 2017
}

\begin{abstract}
Allotransplantation and xenotransplantation may be associated with the transmission of pathogens from the donor to the recipient. Whereas in the case of allotransplantation the transmitted microorganisms and their pathogenic effect are well characterized, the possible influence of porcine microorganisms on humans is mostly unknown. Porcine circoviruses (PCVs) are common in pig breeds and they belong to porcine microorganisms that still have not been fully addressed in terms of evaluating the potential risk of xenotransplantation using pig cells, tissues, and organs. Two types of PCVs are known: porcine circovirus (PCV) 1 and PCV2. Whereas PCV1 is apathogenic in pigs, PCV2 may induce severe pig diseases. Although most pigs are subclinically infected, we do not know whether this infection impairs pig transplant functionality, particularly because PCV2 is immunosuppressive. In addition, vaccination against PCV2 is able to prevent diseases, but in most cases not transmission of the virus. Therefore, PCV2 has to be eliminated to obtain xenotransplants from uninfected healthy animals. Although there is evidence that PCV2 does not infect-at least immunocompetent-humans, animals should be screened using sensitive methods to ensure virus elimination by selection, Cesarean delivery, vaccination, or embryo transfer.
\end{abstract}

Keywords: porcine circoviruses; transspecies transmission of viruses; xenotransplantation; virus safety of xenotransplantation

\section{Introduction}

Allotransplantation can be associated with transmission of microorganisms which induce severe diseases in the recipient [1,2]. Among the transmitted microorganisms are bacteria [3] and viruses such as the human immunodeficiency virus-1 [4], rabies virus [5-7], and human cytomegalovirus (HCMV) [8]. Infection with HCMV is a common complication after transplantation of different organs and contributes significantly to morbidity and mortality, both by direct and indirect mechanisms [9]. Therefore, HCMV status has to be determined and transplantations from HCMV-positive individuals to HCMV-negative individuals are generally avoided (for review see [8,9]). If necessary, an antiviral treatment is available and new antiviral drugs are under development [10]. Xenotransplantation using pig cells, tissues, and organs may also be associated with transmission of microorganisms, including bacteria, viruses, and others from the donor pig [11]. Transmission of porcine cytomegalovirus (PCMV) with the transplant and its increased replication, also called reactivation, on the background of the absence of the pig immune system and of the applied immunosuppression in the non-human primate recipient, was observed after pig kidney transplantations into baboons [12] or cynomolgus monkeys [13]. Transmission of PCMV was also observed after pig heart transplantations into baboons [14]. Although the virus titre in the recipients increases, it is unclear whether PCMV is able to infect cells of the recipient or is replicating only in the cells of the transplant.

There are obvious differences between the transmission inside the human species during allotransplantation and transspecies transmission into a new species during xenotransplantation. Human microorganisms are adapted to humans and can be easily transmitted $[1-4,8,9]$. The porcine 
microorganisms are not adapted to humans, and it is clear that many of them cannot infect human cells due to the absence of a receptor or due to cellular factors restricting replication in human cells. In contrast to human pathogens, sensitive detection methods for porcine microorganisms were developed only in a few specialized laboratories, and it is unclear whether commercial test laboratories can detect low virus load infections, as shown in one case of PCMV infection [15]. Sending identical virus dilutions to different laboratories worldwide for testing, so called round robin tests, may answer this question. The results of the testing will indicate the sensitivity of their methods. In this context, in a recent round robin or ring test including 11 North American laboratories, the most sensitive assay detected DNA levels of a porcine virus about 100,000 times lower than the least sensitive assay [16]. This study demonstrated that the polymerase chain reaction (PCR) assays available in these diagnostic labs vary considerably in their detection limits and quantification.

Even if porcine microorganisms can infect humans and replicate, it is still unclear whether they are pathogenic. For example, hepatitis E virus (HEV) genotype 3 coming from pigs mostly induces diseases in chronically ill and immunosuppressed humans, but not in healthy individuals [17], although the influence of the subclinical infection on the health of the infected person is still unknown.

The porcine circoviruses (PCVs) belong to the genus Circovirus of the family Circoviridae [18]. Porcine circovirus 1 (PCV1) was first described at the Robert Koch Institute, Berlin [19]. Other members of this family are PCV2, several avian circoviruses [18], and recently new circoviruses have been isolated from mammals: bat [20,21], dogs [22-25], mink [26,27], and others. Circoviruses are non-enveloped spherical (16-18 nm) particles (Figure 1) with a single-stranded and circular small DNA genome. PCVs are the smallest viruses found to be replicating in mammalian cells. PCVs are quite stable, the effectiveness of disinfectants for reducing PCV2 in vitro is variable and PCV2 is very stable in the pig environment. The virus is very resistant under high temperatures and a wide range of $\mathrm{pH}$ conditions (for review see [28]). Two major open reading frames (orfs) have been recognized. Orf1 encodes the two replicases indispensable for viral replication (Rep and Rep'), and orf 2 encodes the capsid protein Cap, which is the major structural protein [29]. Three other genes, orf3, orf4, and orf 5 encode proteins not essential for virus replication, but involved in the virulence and spread of the virus [30,31]. Cells of the monocyte and macrophage lineage have consistently been shown to be targets for porcine circovirus replication in vivo, and appear to be important in the pathogenesis of the postweaning multisystemic wasting syndrome (PMWS) [32-34]. Additionally, a variety of other cell types, including hepatocytes, enterocytes, renal and alveolar epithelial cells, vascular endothelial cells, pancreatic acinar and ductular cells, lymphocytes, smooth muscle cells, and fibroblasts, have also been shown to contain PCV2 antigens and/or nucleic acid [35]. It was shown that heparin, heparan sulphate, and chondroitin sulphate are attachment factors for PCV2 [36], whereas the main receptor is still unknown [37].

PCV1 is apathogenic in pigs, but PCV2 is associated with severe diseases, among them PMWS, which is considered the most significant PCV2-related disease (PCVD) (see Section 3). PCV2 is an immunosuppressive virus, targeting the lymphoid tissues, which leads to lymphoid depletion and immunosuppression in pigs. The virus resides in immune cells, such as macrophage and dendritic cells, and modulates their functions. Upregulation of interleukin (IL)-10 and proinflammatory cytokines in infected pigs may contribute to pathogenesis and co-infection with other pathogens. PCV2 DNA and proteins interact with various cellular genes that control immune responses [38-40]. Although numerous reviews summarise the impact of PCV2 on pig production and give detailed descriptions of the pathogenesis of PCV2-induced diseases in pigs [40-43], this review is the first to analyse the potential impact of PCV2 on xenotransplantation, and to analyse whether PCV2 may represent a risk for xenotransplantation. PCV2 induces severe diseases in pigs, but it remains unclear whether subclinical infections may reduce the quality of the pig transplants, particularly because the virus is immunosuppressive. Vaccination against PCV2 is able to prevent diseases, but in most cases is unable to prevent the transmission of the virus (for details see Section 6). Using sensitive methods will increase the probability of detecting the virus. However, it remains unclear how sensitive these 
methods should be. At the very least, in order to prevent transmission during xenotransplantation, the sensitivity of the detection methods should allow for the detection of the virus below the load which is able to be transmitted and to induce zoonosis [44]. We also indicate different strategies to eliminate the viruses from the donor pig herd in order to prevent transmission to human recipients.

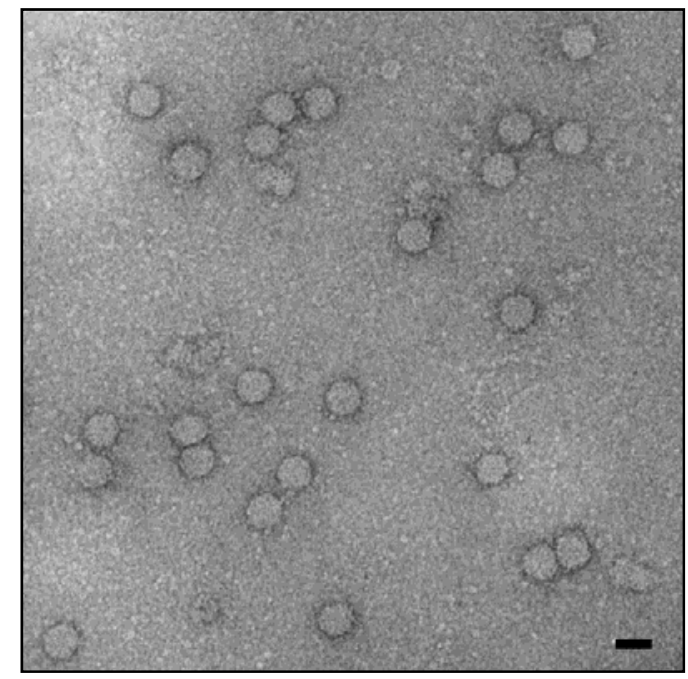

Figure 1. Electron microscopy of porcine circovirus (PCV), negative staining with uranyl acetate. The scale bar corresponds to $20 \mathrm{~nm}$. Hans Gelderblom, Michael Laue, Robert Koch-Institute.

\section{Diagnosis and Transmission}

PCR is a sensitive method of choice to detect a circovirus infection in viremic animals and different PCR assays, including real-time PCR or quantitative PCR (qPCR) and digital droplet PCR (ddPCR) using specific primers for PCV1 and PCV2 have been developed and applied [45-50]. In some cases, PCVs were detected simultaneously with other porcine viruses using multiplex PCR [51,52]. Other detection methods are antibody-based methods such as enzyme-linked immunosorbent assay (ELISA), Western blot analysis, and immunofluorescence [53-58]. The use of saliva for antibody detection gained popularity because of the ease of use and associated cost-saving [59]. Serum antibodies to PCV1 and PCV2 have been demonstrated in a large percentage of pigs in different countries at a time when vaccination had not yet been introduced [60]. PCR screening in the year 2000 of randomly collected 109 organ samples from German pigs not affected with PCVD revealed a rate of infection with PCV1 of 5\% and with PCV2 of $26.8 \%$ [46]. Seroconversion usually occurs by two to four months of age irrespective of whether clinical signs of PCVD are observed. PCV2 is shed for a long time by different routes, both after natural as well as experimental infection [61,62]. Therefore, it easily spreads within the population, mainly by direct contact with contaminated respiratory, digestive, and urinary secretions. Although PCV2 has been identified in the semen of acutely affected boars, transmission of the virus via this route has not been documented in a field setting $[63,64]$.

Based on phylogenetic analysis, PCV2 is divided into different genotypes (PCV2a, PCV2b, PVC2c, PCV2d, PCV2e, PCV2f) [65]. The first three variants show 97\%-100\% nucleotide identity in the rep gene and $91 \%-96 \%$ in the cap gene [66]. They are believed to have evolved from a common ancestor 100 years ago [67]. In recent years, evidence has accumulated for a global shift of the main PCV2 genotypes in different countries from PCV2a to PCV2b, which is generally associated with more severe disease symptoms [68,69]. PCV2d was initially identified in Switzerland, now it appears to be widespread in China and North America. During 2012-2013, 37\% of all investigated PCV2 sequences from U.S. pigs were classified as PCV2d, and overall data analysis suggests an ongoing genotype shift from PCV2b towards PCV2d [70]. Recombinations and mutations have been often observed and may result in altered fitness or phenotypic properties [71-73]. 
Since changes in the nucleotide sequence of genomic regions used as targets for PCR-detection of PCV may result in false-negative findings, the primers must be checked routinely by a Basic Local Alignment Search Tool (BLAST) search of GenBank for their fitness to detect new variants. If no highly conserved regions can be identified and problems related to genomic variation are anticipated, multiplex PCRs for different viral variants using more than one primer pair or next generation sequencing can be employed.

Recently, a new virus, PCV3, with significant differences in the sequence when compared with PCV1 and PCV2, but more related to a bat-faeces associated circovirus, was described in pigs with cardiac and multi-organ inflammation [74]. Since the pigs were co-infected with other porcine viruses, the pathogenicity of PCV3 warrants further investigations. PCV3 was found to be associated with porcine dermatitis and nephropathy syndrome (PDNS), reproductive failure, and multisystemic inflammation in China $[75,76]$ and in the USA [77]. Sequence analysis showed that the Chinese isolates are the result of a recombination between bat circoviruses [76], and the closest relative of the U.S.A. isolate is a canine circovirus [77].

\section{PCV2-Related Diseases in Pigs}

PCVD was first detected in the early 1990s and has since then emerged as an economically important pig disease worldwide [61]. The main disease induced by PCV2 is PMWS [41,42]. However, PCV2 induces an entire complex of diseases now called PCVD in Europe or PCV-associated disease (PCVAD) in North America [33]. PCVD can be subdivided into PCV2-systemic disease (PCV2-SD, directly replacing PMWS), PCV2-subclinical infection (PCV2-SI), PCV2-reproductive disease (PCV2-RD), and PDNS. PCV2 is necessary but not sufficient for the induction of PCVD. Some purported risk factors include coinfection with other viruses. Porcine reproductive and respiratory syndrome virus (PRRSV) is one of these viruses, it causes the porcine reproductive and respiratory syndrome associated with reproductive failure in breeding stocks and respiratory tract illness in young pigs. Co-infection with porcine parvovirus may also contribute to PCVD as well as nonspecific immune stimulation (e.g., by vaccination).

Clinical signs of the disease include gradual wasting, fever, rough hair coat, dyspnea, pallor, diarrhea, and occasionally icterus. PCVD is characterized by lymphoid depletion, immunosuppression, and inflammation in affected organs. Morbidity varies from $2 \%-30 \%$, but case fatality is high, approaching $80 \%$. Occasionally, pigs may develop purple skin lesions and nephropathy, likely as an immune mediated sequel to viral infection, termed PDNS [78,79]. Occasionally reproductive failure is observed as abortions, stillbirths, and mummification (PCV2-RD) $[62,80,81]$.

\section{PCV Does Not Infect Immunocompetent Humans}

When trying to infect human cell lines with PCV1 and PCV2, PCV1 persisted in most cell lines without causing any visible changes, while PCV2-transfected cells showed a cytopathogenic effect [82]. Most importantly, in both cases the infection was non-productive [82,83]. Infection with PCV1 was observed in human 293, HeLa, and Chang liver cells, whereas PCV2 infected only human Rd cells [82]. Although it is well known that, in addition to PCV2, outbreaks of PCVD in pigs require cofactors (e.g., PRRSV), co-infecting human cells with PCV2 and PRRSV was not yet performed. In addition to cell lines, primary human leukocytes could also be infected with PCV1, inducing severe morphological alterations in the infected cells [84], indicating that PCV1 may also be pathogenic.

When humans were screened for antibodies against PCV, in an early study, antibodies to PCV were found in $30 \%$ of samples from hospitalized patients with fever of unknown etiology [85]. These results are in striking contrast to those from another group that did not detect antibodies in serum samples from the general population and from veterinarians working with PCVD affected animals [61]. Additional studies are necessary to confirm the latter negative results.

A large "experiment" testing the susceptibility of the human population to PCV was involuntary conducted when two vaccines against rotaviral gastroenteritis from two different manufacturers 
were found to be contaminated with PCV1 and PCV2 [86-88]. Both contaminated vaccines had been used world-wide for a number of years, preventing disease and saving millions of children's lives [89,90]. Over $10^{5}$ or $10^{6}$ particle-associated full-length PCV1 genomes were present in each dose of the contaminated vaccine [83,87-89], and cell culture assays in swine testis and PCV-free porcine kidney (PK-15) cells confirmed that PCV1 sequences in this vaccine represented infectious virus [86-88,91]. Another rotavirus vaccine contained only subgenomic PCV1 and PCV2 fragments, but no full-length PCV genomes, and cell culture assays did not amplify PCV from this vaccine [88]. When stool samples from children vaccinated with Rotarix, an oral live attenuated vaccine based on the human rotavirus RIX4414 produced by GlaxoSmithKline (London, UK), were analyzed, in 4 of 40 samples PCV1 DNA was detected [83]. PCV1 DNA was detected only soon after vaccination, indicating that viral replication did not occur in the gastrointestinal tract. Antibodies were not detected in the sera of vaccinated children, confirming that no replication of the virus had taken place. The pattern of adverse events reported in vaccinated infants with PCV1 in their stool did not differ from that observed in placebo recipients [83]. This correlated with the reports that the Rotarix vaccine in general had nearly no adverse events $[89,90]$.

However-and this is the main question in the context of xenotransplantation-up until now it is still unknown whether PCV is zoonotic in severely immunosuppressed humans.

\section{PCV2 and First Preclinical and Clinical Xenotransplantations}

In all of the clinical xenotransplantation trials documented in Paradise et al. [92], no screening for PCV was performed in the Large White donor pigs and human recipients. Auckland Island pigs were used as source for the first clinical pig islet cell transplantation to human diabetic patients in New Zealand and Argentina [93-96]. These donor animals were free of PCV1 and PCV2, and therefore could not transmit circoviruses [94]. The sensitivity of the PCR used to detect PCV in Auckland Island pigs was estimated to be $10^{6} \mathrm{mg}$ of DNA per reaction [97]. Islet cells from Auckland Island pigs were also used in a prospective pig-to-primate islet xenotransplantation study, and as expected, no PCV was transmitted [98]. In most of the reported pig-to-non-human primate transplantations, no screening for PCV was performed, with the exception of a the just mentioned trial transplanting islet cells from Auckland Island pigs into cynomolgus monkeys [98]. In addition, pig donors for islet cell transplantation into mice had also been found to be PCV-negative [99]. Recently, islet cells from Large White/Yorkshire landrace F1 pigs were transplanted into non-immunosuppressed cynomolgus monkeys, and no PCV was detected in the recipients [100]. Testing was performed based on the presence of PCV in the source herd, although the donor pigs had been vaccinated with CircoFLEX (Table 1). PCV was not tested in the monthly herd screening and in the sentinel and pancreas donor post-mortem screening, the islet cells had been encapsulated in macrobeads.

Table 1. Protective vaccines against PCV2 [101,102].

\begin{tabular}{ccc}
\hline Vaccine & Producer & Vaccine Based on \\
\hline $\begin{array}{c}\text { Circumvent PCV, Porcilis PCV, } \\
\text { Circumvent G2 PCV }\end{array}$ & $\begin{array}{c}\text { MSD/Merck Animal Health (Madison, } \\
\text { New Jersey, United States) }\end{array}$ & $\begin{array}{c}\text { PCV2a Cap protein expressed } \\
\text { by baculovirus }\end{array}$ \\
\hline Ingelvac CircoFLEX & $\begin{array}{c}\text { Boehringer-Ingelheim (St. Joseph, } \\
\text { Missouri, United States) }\end{array}$ & $\begin{array}{c}\text { PCV2a Cap protein expressed } \\
\text { by baculovirus }\end{array}$ \\
\hline Fostera PCV, Suvaxyn PCV & $\begin{array}{c}\text { Zoetis (Parsippany, New Jersey, } \\
\text { United States) }\end{array}$ & $\begin{array}{c}\text { Inactivated recombinant PCV1 } \\
\text { expressing the PCV2a Cap protein } \\
\text { (ORF2 from PCV2) }\end{array}$ \\
\hline Circovac & Merial (Lyon France) & Inactivated whole PCV2a \\
\hline & ORF: Open reading frame. &
\end{tabular}


In future preclinical, as well as clinical trials, donor pigs-and, if necessary, also recipients-should be screened for the presence of circoviruses. When PCV is not found in the donor pig, no screening of the recipients needs to be performed.

\section{Treatment and Vaccination}

There is no specific treatment for pigs with PCVD. Anti-inflammatory agents and antimicrobials may help to suppress co-factors and secondary diseases associated with PCVD. All in/all out pig flow, thorough cleaning, and rigid disinfection between batches of pigs are measures that can help control the disease [103]. In the case that the donor animal is PCV-infected, it may be considered to analyze whether the xenotransplantation product (e.g., isolated islet cells) is still negative. Since PCV2 is infecting macrophages, certainly all organs are infected and it will be safer to use only negative animals, especially since no effective antiviral treatment is available. PCV2 infection is associated with an immune response including neutralising antibodies, and these coincide with a decrease in serum virus load. Cell-mediated immunity has also been shown to be necessary to control PCV2 infection (for review see [102]). PCV2 vaccines became commercially available in the summer of 2006 (Table 1) [103]. The vaccines reduced the severity and incidence rate of PCVD on many farms. Vaccination against PCV2 did not only imply a direct beneficial effect on pig productivity, but also contributed to reduction of antimicrobial use [104]. PCV2 vaccines effectively increased average daily weight gain (ADWG) and prevented diseases with a positive result for meat production. In all vaccination trials a lower virus load was registered in the vaccinated animals, however, it remains unclear whether the virus load is reduced to zero. In most reported cases, virus transmission took place despite vaccination [102,105-107]. In a study vaccinating 28 pigs, the virus load was not reduced to zero in any of the animals [108]. In another study, 17 of 32 vaccinated animals still showed PCV in the serum, as measured by PCR [90]. PCV2 vaccination of sows was associated with high antibody responses, but did not prevent fetal infections in utero or soon after birth by infectious colostrum in 29 of 100 cases [107]. When comparing four different vaccines, use of the inactivated chimeric vaccines (Fostera PCV and Circovax) resulted in significantly lower viremia compared with use of the subunit vaccines (Circoflex, Porcilis PCV), however, histopathological lesions and PCV antigens were still detected in all 80 immunized animals [109]. Successful vaccination is mainly associated with induction of neutralizing antibodies, but $\mathrm{T}$ cell-mediated immunity also plays a role in the reduction of the virus load and prevention of diseases as mentioned above [102,110].

Since new PCV2 variants have emerged, the question of whether or not current vaccines can protect against new PCV2 variants that may be more virulent for pigs becomes a serious concern. Although it is still unclear whether the global switch from PCV2a to PCV2b and PCV2d was associated with higher fitness of PCV2, as reported [68,69], rather than vaccine induced selection pressure, the emergence and rapid spread of new PCV2 variants provide evidence that current vaccines need to be updated.

\section{How to Eliminate PCV}

For a safe xenotransplantation, elimination programs have been proposed for porcine viruses such as HEV [17], PCMV [111], porcine lymphotropic herpesviruses, and others [112], by isolation of virus-free animals, treatment, and vaccination. Elimination programs in the case of circoviruses should be based on (i) selection of animals found non-infected using highly sensitive detection methods to avoid false-negative testing; (ii) vaccination or other strategies (see below), since treatment is not available; and (iii) isolation of virus-negative animals to prevent de novo infection. Elimination means elimination from the herd, elimination from a single individual is impossible, since there is no treatment presently available. The efficacy of the vaccines should be improved and new vaccines against emerging variant virus strains should be developed. Since PCV2 is easily transmitted through the placenta and since colostrum was shown to be infectious, Cesarean section, and colostrum derivation are two promising strategies to eliminate PCV $[80,106,107,113]$. Recent findings of PCV2 in Göttingen 
Minipigs [114], which were introduced into the facility by Cesarean delivery and are produced under specified pathogen-free breeding conditions that are very similar to designated pathogen-free breeding conditions [115], confirm transmission through the placenta and indicate that selection of PCV2-free animals may be difficult. However, when 384 embryos recovered from PCV2 infected pigs 10 days after inoculation were transferred to seronegative donors, no infection of the recipient pig and the piglets was observed, indicating that embryo transfer can be successfully used for the elimination of PCV2 [116].

\section{Summary}

PCV2 is a very small virus, it is stable and resistant to some disinfectants, $\mathrm{pH}$, and heat, and it induces severe diseases in infected pigs. PCV2 is an immunosuppressive virus and it is still unclear whether subclinical infections of pigs may decrease the functionality of the organs required for transplantation. Vaccination against PCV2 is able to prevent diseases, but in most cases is unable to prevent the transmission of the virus. Although PCV2 infects human cells and induces a cytopathic effect in vitro, no pathogenic effects were observed when PCV was transmitted by contaminated vaccines to children. It remains unknown whether PCV may infect severely immunosuppressed individuals. In conclusion, for all of these reasons, sensitive detection methods should be used to screen for the virus and improved vaccination, Cesarean delivery, colostrum deprivation, and embryo transfer should be used to prevent transmission of the virus.

Acknowledgments: This study was supported in part by a grant from the German Research Foundation (Deutsche Forschungsgemeinschaft), TRR 127, to J.D.

Author Contributions: Both of the authors reviewed the literature and wrote the manuscript.

Conflicts of Interest: The authors declare no conflict of interest.

\section{References}

1. Fishman, J.A. Infection in solid-organ transplant recipients. N. Engl. J. Med. 2007, 357, 2601-2614. [CrossRef] [PubMed]

2. Romero, F.A.; Razonable, R.R. Infections in liver transplant recipients. World J. Hepatol. 2011, 3, 83-92. [CrossRef] [PubMed]

3. Kim, S. Bacterial infection after liver transplantation. World J. Gastroenterol. 2014, 20, 6211-6220. [CrossRef] [PubMed]

4. Petrosillo, N.; Puro, V.; D’Anna, C.; Marquez, J.R.; Ippolito, G. HIV infection after kidney transplantation. Nephron 1996, 72, 124. [CrossRef] [PubMed]

5. Vora, N.M.; Basavaraju, S.V.; Feldman, K.A.; Paddock, C.D.; Orciari, L.; Gitterman, S.; Griese, S.; Wallace, R.M.; Said, M.; Blau, D.M.; et al. Raccoon rabies virus variant transmission through solid organ transplantation. JAMA 2013, 310, 398-407. [CrossRef] [PubMed]

6. Maier, T.; Schwarting, A.; Mauer, D.; Ross, R.S.; Martens, A.; Kliem, V.; Wahl, J.; Panning, M.; Baumgarte, S.; Müller, T.; et al. Management and outcomes after multiple corneal and solid organ transplantations from a donor infected with rabies virus. Clin. Infect. Dis. 2010, 50, 1112-1119. [CrossRef] [PubMed]

7. Srinivasan, A.; Burton, E.C.; Kuehnert, M.J.; Rupprecht, C.; Sutker, W.L.; Ksiazek, T.G.; Paddock, C.D.; Guarner, J.; Shieh, W.J.; Goldsmith, C.; et al. Transmission of rabies virus from an organ donor to four transplant recipients. N. Engl. J. Med. 2005, 352, 1103-1111. [CrossRef] [PubMed]

8. Ramanan, P.; Razonable, R.R. Cytomegalovirus infections in solid organ transplantation: A review. Infect. Chemother. 2013, 45, 260-271. [CrossRef] [PubMed]

9. Razonable, R.R. Cytomegalovirus infection after liver transplantation: Current concepts and challenges. World J. Gastroenterol. 2008, 14, 4849-4860. [CrossRef] [PubMed]

10. Lischka, P.; Zimmermann, H. Antiviral strategies to combat cytomegalovirus infections in transplant recipients. Curr. Opin. Pharmacol. 2008, 8, 541-548. [CrossRef] [PubMed]

11. Fishman, J.A. Assessment of infectious risk in clinical xenotransplantation: The lessons for clinical allotransplantation. Xenotransplantation 2014, 21, 307-308. [CrossRef] [PubMed] 
12. Yamada, K.; Tasaki, M.; Sekijima, M.; Wilkinson, R.A.; Villani, V.; Morgan, S.G.; Cormack, T.A.; Hanekamp, I.M.; Hawley, R.J.; Arn, J.S.; et al. Porcine cytomegalovirus infection is associated with early rejection of kidney grafts in a pig to baboon xenotransplantation model. Transplantation 2014, 98, 411-418. [CrossRef] [PubMed]

13. Sekijima, M.; Waki, S.; Sahara, H.; Tasaki, M.; Wilkinson, R.A.; Villani, V.; Shimatsu, Y.; Nakano, K.; Matsunari, H.; Nagashima, H.; et al. Result of life-supporting galactosyltransferase knockout swine. Transplantation 2014, 98, 419-426. [CrossRef] [PubMed]

14. Morozov, V.A.; Abicht, J.M.; Reichart, B.; Mayr, T.; Guethoff, S.; Denner, J. Active replication of porcine cytomegalovirus (PSMV) following transplantation of a pig heart into a baboon despite undetected virus in the donor pig. Ann. Virol. Res. 2016, 2, 1018.

15. Morozov, V.A.; Plotzki, E.; Rotem, A.; Barkai, U.; Denner, J. Extended microbiologicial characterization of Göttingen minipigs: Porcine cytomegalovirus and other viruses. Xenotransplantation 2016, 24, 34-40.

16. Harding, J.C.; Baker, C.; Rhodes, C.; McIntosh, K.A.; Bonneau, M. Ring tests to evaluate the performance of porcine circovirus-2 (PCV-2) polymerase chain reaction (PCR) assays used in North American diagnostic laboratories. Can. J. Vet. Res. 2009, 73, 7-14. [PubMed]

17. Denner, J. Xenotransplantation and hepatitis E virus. Xenotransplantation 2015, 22, 167-173. [CrossRef] [PubMed]

18. Finsterbusch, T.; Mankertz, A. Porcine circoviruses-Small but powerful. Virus Res. 2009, 143, $177-183$. [CrossRef] [PubMed]

19. Tischer, I.; Rasch, R.; Tochtermann, G. Characterization of papovavirus-and picornavirus-like particles in permanent pig kidney cell lines. Zentralbl. Bakteriol. Orig. A. 1974, 226, 153-167. [PubMed]

20. Lima, F.E.; Cibulski, S.P.; Dall Bello, A.G.; Mayer, F.Q.; Witt, A.A.; Roehe, P.M.; d'Azevedo, P.A. A novel chiropteran circovirus genome recovered from a Brazilian insectivorous bat species. Genome Announc. 2015, 3, e01393-15. [CrossRef] [PubMed]

21. Han, H.J.; Wen, H.L.; Zhao, L..; Liu, J.W.; Luo, L.M.; Zhou, C.M.; Qin, X.R.; Zhu, Y.L.; Liu, M.M.; Qi, R.; et al. Novel coronaviruses; astroviruses; adenoviruses and circoviruses in insectivorous bats from northern China. Zoonoses Public Health 2017. [CrossRef]

22. Kapoor, A.; Dubovi, E.J.; Henriquez-Rivera, J.A.; Lipkin, W.I. Complete genome sequence of the first canine circovirus. J. Virol. 2012, 86, 7018. [CrossRef] [PubMed]

23. Zaccaria, G.; Malatesta, D.; Scipioni, G.; Di Felice, E.; Campolo, M.; Casaccia, C.; Savini, G.; Di Sabatino, D.; Lorusso, A. Circovirus in domestic and wild carnivores: An important opportunistic agent? Virology 2016, 490, 69-74. [CrossRef] [PubMed]

24. Thaiwong, T.; Wise, A.G.; Maes, R.K.; Mullaney, T.; Kiupel, M. Canine circovirus 1 (CaCV-1) and canine parvovirus 2 (CPV-2): Recurrent dual Infections in a Papillon breeding colony. Vet. Pathol. 2016, 53, 1204-1209. [CrossRef] [PubMed]

25. Anderson, A.; Hartmann, K.; Leutenegger, C.M.; Proksch, A.L.; Mueller, R.S.; Unterer, S. Role of canine circovirus in dogs with acute haemorrhagic diarrhoea. Vet. Rec. 2017. [CrossRef] [PubMed]

26. Lian, H.; Liu, Y.; Li, N.; Wang, Y.; Zhang, S.; Hu, R. Novel circovirus from mink; China. Emerg. Infect. Dis. 2014, 20, 1548-1550. [CrossRef] [PubMed]

27. Wang, G.S.; Sun, N.; Tian, F.L.; Wen, Y.J.; Xu, C.; Li, J.; Chen, Q.; Wang, J.B. Genetic analysis of porcine circovirus type 2 from dead minks. J. Gen. Virol. 2016, 97, 2316-2322. [CrossRef] [PubMed]

28. Patterson, A.R.; Opriessnig, T. Epidemiology and horizontal transmission of porcine circovirus type 2 (PCV2). Anim. Health Res. Rev. 2010, 11, 217-234. [CrossRef] [PubMed]

29. Finsterbusch, T.; Steinfeldt, T.; Doberstein, K.; Rödner, C.; Mankertz, A. Interaction of the replication proteins and the capsid protein of porcine circovirus type 1 and 2 with host proteins. Virology 2009, 386, 122-131. [CrossRef] [PubMed]

30. Lv, Q.; Guo, K.; Wang, T.; Zhang, C.; Zhang, Y. Porcine circovirus type 2 ORF4 protein binds heavy chain ferritin. J. Biosci. 2015, 40, 477-485. [CrossRef] [PubMed]

31. Lv, Q.; Guo, K.; Xu, H.; Wang, T.; Zhang, Y. Identification of putative ORF5 protein of porcine circovirus type 2 and functional analysis of GFP-fused ORF5 protein. PLOS ONE 2015, 10, e0127859.

32. Allan, G.M.; McNeilly, F.; Foster, J.C.; Adair, B.M. Infection of leucocyte cell cultures derived from different species with pig circovirus. Vet. Microbiol. 1994, 41, 267-279. [CrossRef] 
33. Sanchez, R.E., Jr.; Meerts, P.; Nauwynck, H.J.; Pensaert, M.B. Change of porcine circovirus 2 target cells in pigs during development from fetal to early postnatal life. Vet. Microbiol. 2003, 95, 15-25. [CrossRef]

34. Meerts, P.; Misinzo, G.; McNeilly, F.; Nauwynck, H.J. Replication kinetics of different porcine circovirus 2 strains in PK-15 cells, fetal cardiomyocytes and macrophages. Arch. Virol. 2005, 150, 427-441. [CrossRef] [PubMed]

35. Darwich, L.; Segales, J.; Mateu, E. Pathogenesis of postweaning multisystemic wasting syndrome caused by porcine circovirus 2: An immune riddle. Arch. Virol. 2004, 149, 857-874. [CrossRef] [PubMed]

36. Jolly, C.L.; Sattentau, Q.J. Attachment factors. Adv. Exp. Med. Biol. 2013, 790, 1-23. [PubMed]

37. Misinzo, G.; Delputte, P.L.; Meerts, P.; Lefebvre, D.J.; Nauwynck, H.J. Porcine circovirus 2 uses heparan sulfate and chondroitin sulfate B glycosaminoglycans as receptors for its attachment to host cells. J. Virol. 2006, 80, 3487-3494. [CrossRef] [PubMed]

38. Meng, X.-J. Porcine circovirus type 2 (PCV2): Pathogenesis and interaction with the immune system. Annu. Rev. Anim. Biosci. 2013, 1, 43-64. [CrossRef] [PubMed]

39. Segalés, J.; Mateu, E. Immunosuppression as a feature of postweaning multisystemic wasting syndrome. Vet. J. 2006, 171, 396-397. [CrossRef] [PubMed]

40. Gillespie, J.; Opriessnig, T.; Meng, X.J.; Pelzer, K.; Buechner-Maxwell, V. Porcine circovirus type 2 and porcine circovirus-associated disease. J. Vet. Intern. Med. 2009, 23, 1151-1163. [CrossRef] [PubMed]

41. Segalés, J.; Allan, G.M.; Domingo, M. Porcine circovirus diseases. Anim. Health Res. Rev. 2005, 6, 119-142. [CrossRef] [PubMed]

42. Opriessnig, T.; Langohr, I. Current state of knowledge on porcine circovirus type 2-associated lesions. Vet. Pathol. 2013, 50, 23-38. [CrossRef] [PubMed]

43. Opriessnig, T.; Meng, X.J.; Halbur, P.G. Porcine circovirus type 2 associated disease: Update on current terminology, clinical manifestations, pathogenesis, diagnosis, and intervention strategies. J. Vet. Diagn. Investig. 2007, 19, 591-615. [CrossRef] [PubMed]

44. Denner, J. Sensitive methods and improved screening strategies are needed for the detection of pig viruses. Xenotransplantation. in press.

45. Quintana, J.; Segalés, J.; Calsamiglia, M.; Domingo, M. Detection of porcine circovirus type 1 in commercial pig vaccines using polymerase chain reaction. Vet. J. 2006, 171, 570-573. [CrossRef] [PubMed]

46. Segalés, J.; Calsamiglia, M.; Olvera, A.; Sibila, M.; Badiella, L.; Domingo, M. Quantification of porcine circovirus type 2 (PCV2) DNA in serum and tonsillar, nasal, tracheo-bronchial, urinary and faecal swabs of pigs with and without postweaning multisystemic wasting syndrome (PMWS). Vet. Microbiol. 2005, 111, 223-229. [CrossRef] [PubMed]

47. Mankertz, A.; Domingo, M.; Folch, J.M.; LeCann, P.; Jestin, A.; Segalés, J.; Chmielewicz, B.; Plana-Durán, J.; Soike, D. Characterisation of PCV-2 isolates from Spain, Germany and France. Virus Res. 2000, 66, 65-77. [CrossRef]

48. Wang, J.; Wang, J.; Liu, L.; Li, R.; Yuan, W. Rapid detection of Porcine circovirus 2 by recombinase polymerase amplification. J. Vet. Diagn. Investig. 2016, 28, 574-578. [CrossRef] [PubMed]

49. Zhao, S.; Lin, H.; Chen, S.; Yang, M.; Yan, Q.; Wen, C.; Hao, Z.; Yan, Y.; Sun, Y.; Hu, J.; et al. Sensitive detection of Porcine circovirus-2 by droplet digital polymerase chain reaction. J. Vet. Diagn. Investig. 2015, 27, 784-788. [CrossRef] [PubMed]

50. Wang, C.; Pang, V.F.; Lee, F.; Liao, P.C.; Huang, Y.L.; Lin, Y.L.; Lai, S.S.; Jeng, C.R. Development and evaluation of a loop-mediated isothermal amplification method for rapid detection and differentiation of two genotypes of porcine circovirus type 2. J. Microbiol. Immunol. Infect. 2014, 47, 363-370. [CrossRef] [PubMed]

51. Pérez, L.J.; Perera, C.L.; Frías, M.T.; Núñez, J.I.; Ganges, L.; de Arce, H.D. A multiple SYBR Green I-based real-time PCR system for the simultaneous detection of porcine circovirus type 2; porcine parvovirus; pseudorabies virus and Torque teno sus virus 1 and 2 in pigs. J. Virol. Methods. 2012, 179, 233-241. [CrossRef] [PubMed]

52. Blomström, A.L.; Belák, S.; Fossum, C.; Fuxler, L.; Wallgren, P.; Berg, M. Studies of porcine circovirus type 2; porcine boca-like virus and torque teno virus indicate the presence of multiple viral infections in postweaning multisystemic wasting syndrome pigs. Virus Res. 2010, 152, 59-64. [CrossRef] [PubMed]

53. Blanchard, P.; Mahé, D.; Cariolet, R.; Truong, C.; Le Dimna, M.; Arnauld, C.; Rose, N.; Eveno, E.; Albina, E.; Madec, F.; et al. An ORF2 protein-based ELISA for porcine circovirus type 2 antibodies in post-weaning multisystemic wasting syndrome. Vet. Microbiol. 2003, 94, 183-194. [CrossRef] 
54. Liu, Q.; Wang, L.; Willson, P.; O'Connor, B.; Keenliside, J.; Chirino-Trejo, M.; Babiuk, L. Seroprevalence of porcine circovirus type 2 in swine populations in Canada and Costa Rica. Can. J. Vet. Res. 2002, 66, 225-231. [PubMed]

55. Patterson, A.R.; Johnson, J.; Ramamoorthy, S.; Ramamoorthy, S.; Meng, X.J.; Halbur, P.G.; Opriessnig, T. Comparison of three enzyme-linked immunosorbent assays to detect porcine circovirus-2 (PCV-2)-specific antibodies after vaccination or inoculation of pigs with distinct PCV-1 or PCV-2 isolates. J. Vet. Diagn. Investig. 2008, 20, 744-751. [CrossRef] [PubMed]

56. Mahé, D.; Blanchard, P.; Truong, C.; Arnauld, C.; Le Cann, P.; Cariolet, R.; Madec, F.; Albina, E.; Jestin, A. Differential recognition of ORF2 protein from type 1 and type 2 porcine circoviruses and identification of immunorelevant epitopes. J. Gen. Virol. 2000, 81, 1815-1824. [CrossRef] [PubMed]

57. Nawagitgul, P.; Harms, P.A.; Morozov, I.; Thacker, B.J.; Sorden, S.D.; Lekcharoensuk, C.; Paul, P.S. Modified indirect porcine circovirus (PCV) type 2-based and recombinant capsid protein (ORF2)-based enzyme-linked immunosorbent assays for detection of antibodies to PCV. Clin. Diagn. Lab. Immunol. 2002, 9, 33-40. [CrossRef] [PubMed]

58. Patterson, A.R.; Johnson, J.K.; Ramamoorthy, S.; Patterson, A.R.; Johnson, J.K.; Ramamoorthy, S.; Hesse, R.A.; Murtaugh, M.P.; Puvanendiran, S.; Meng, X.J. Interlaboratory comparison of porcine circovirus-2 indirect immunofluorescent antibody test and enzyme-linked immunosorbent assay results on experimentally infected pigs. J. Vet. Diagn. Investig. 2011, 23, 206-212. [CrossRef] [PubMed]

59. Ramirez, A.; Wang, C.; Prickett, J.R.; Pogranichniy, R.; Yoon, K.J.; Main, R.; Kurtz, A. Efficient surveillance of pig populations using oral fluids. Prev. Vet. Med. 2012, 104, 292-300. [CrossRef] [PubMed]

60. Allan, G.M.; Ellis, J.A. Porcine circoviruses: A review. J. Vet. Diagn. Investig. 2000, 12, 3-14. [CrossRef] [PubMed]

61. Patterson, A.R.; Madson, D.M.; Halbur, P.G.; Opriessnig, T. Shedding and infection dynamics of porcine circovirus type 2 (PCV2) after natural exposure. Vet. Microbiol. 2011, 149, 225-229. [CrossRef] [PubMed]

62. Patterson, A.R.; Ramamoorthy, S.; Madson, D.M.; Meng, X.J.; Halbur, P.G.; Opriessnig, T. Shedding and infection dynamics of porcine circovirus type 2 (PCV2) after experimental infection. Vet. Microbiol. 2011, 149, 91-98. [CrossRef] [PubMed]

63. Lang, Ch.; Griessler, A.; Pirker, E.; Söllner, H.; Segalés, J.; Kekarainen, T.; Ritzmann, M. Detection of porcine circovirus type 2 and Torque-teno-sus-virus 1 and 2 in semen samples of boars from an Austrian artificial insemination centre. Tierarztl. Prax. Ausg. G. Grosstiere Nutztiere 2011, 39, 201-204. [PubMed]

64. Grasland, B.; Blanchard, P.; Kéranflech, A.; Bigault, L.; Oger, A.; Rose, N.; Madec, F.; Jestin, A.; Cariolet, R. Evaluation of the transmission of porcine circovirus type 2 (PCV-2) genogroups a and $b$ with semen from infected specific-pathogen-free boars. Vet. Microbiol. 2013, 162, 381-387. [CrossRef] [PubMed]

65. Zhai, S.L.; Chen, S.N.; Zhang, J.W.; Wei, Z.Z.; Long, J.X.; Yuan, S.S.; Wei, W.K.; Chen, Q.L.; Wu, H.X.; Wu, D.C. Dissection of the possible routes on porcine circoviruses infecting human. J. Anim. Veterin. Adv. 2012, 11, 1281-1286.

66. Larochelle, R.; Magar, S.; D'Allaire, S. Genetic characterization and phylogenetic analysis of porcine circovirus type 2 (PCV2) strains from cases presenting various clinical conditions. Virus Res. 2002, 90, 101-112. [CrossRef]

67. Firth, C.; Charleston, M.A.; Duffy, S.; Shapiro, B.; Holmes, E.C. Insights into the evolutionary history of an emerging livestock pathogen: Porcine circovirus 2. J. Virol. 2009, 83, 12813-12821. [CrossRef] [PubMed]

68. Segalés, J.; Olvera, A.; Grau-Roma, L.; Charreyre, C.; Nauwynck, H.; Larsen, L.; Dupont, K.; McCullough, K.; Ellis, J.; Krakowka, S.; et al. PCV-2 genotype definition and nomenclature. Vet. Rec. 2008, 162, 867-868. [CrossRef] [PubMed]

69. Rose, N.; Opriessnig, T.; Grasland, B.; Jestin, A. Epidemiology and transmission of porcine circovirus type 2 (PCV2). Virus Res. 2012, 164, 78-89. [CrossRef] [PubMed]

70. Xiao, C.T.; Halbur, P.G.; Opriessnig, T. Global molecular genetic analysis of porcine circovirus type 2 (PCV2) sequences confirms the presence of four main PCV2 genotypes and reveals a rapid increase of PCV2d. J. Gen. Virol. 2015, 96, 1830-1841. [CrossRef] [PubMed]

71. Ssemadaali, M.A.; Ilha, M.; Ramamoorthy, S. Genetic diversity of porcine circovirus type 2 and implications for detection and control. Res. Vet. Sci. 2015, 103, 179-186. [CrossRef] [PubMed] 
72. Hu, J.; Zhai, S.L.; Zeng, S.Y.; Sun, B.B.; Deng, S.F.; Chen, H.L.; Zheng, Y.; Wang, H.X.; Li, X.P.; Liu, J.K.; et al. Identification of natural recombinants derived from PCV2a and PCV2b. Genet. Mol. Res. 2015, 14, 11780-11790. [CrossRef] [PubMed]

73. Gagnon, C.A.; Music, N.; Fontaine, G.; Tremblay, D.; Harel, J. Emergence of a new type of porcine circovirus in swine (PCV): A type 1 and type 2 PCV recombinant. Vet. Microbiol. 2010, 144, 18-23. [CrossRef] [PubMed]

74. Phan, G.T.; Giannitti, F.; Rossow, S.; Marthaler, D.; Knutson, T.; Linlin, L.; Deng, X.; Resende, T.; Vannucci, F.; Delwart, E. Detection of a novel circovirus PCV3 in pigs with cardiac and multi-systemic inflammation. Virol. J. 2016, 13, 184. [CrossRef] [PubMed]

75. Shen, H.; Liu, X.; Zhang, P.; Wang, L.; Liu, Y.; Zhang, L.; Liang, P.; Song, C. Genome characterization of a porcine circovirus type 3 in South China. Transbound. Emerg. Dis. 2017. [CrossRef] [PubMed]

76. Ku, X.; Chen, F.; Li, P.; Wang, Y.; Yu, X.; Fan, S.; Qian, P.; Wu, M.; He, Q. Identification and genetic characterization of porcine circovirus type 3 in China. Transbound. Emerg. Dis. 2017. [CrossRef] [PubMed]

77. Palinski, R.; Piñeyro, P.; Shang, P.; Yuan, F.; Guo, R.; Fang, Y.; Byers, E.; Hause, B.M. A Novel porcine circovirus distantly related to known circoviruses is associated with porcine dermatitis and nephropathy syndrome and reproductive failure. J. Virol. 2016, 91, e01879-16. [CrossRef] [PubMed]

78. Meehan, B.M.; McNeilly, F.; McNair, I.; Walker, I.; Ellis, J.A.; Krakowka, S.; Allan, G.M. Isolation and characterization of porcine circovirus 2 from cases of sow abortion and porcine dermatitis and nephropathy syndrome. Arch. Virol. 2001, 146, 835-842. [CrossRef] [PubMed]

79. Rosell, C.; Segalés, J.; Ramos-Vara, J.A.; Folch, J.M.; Rodríguez-Arrioja, G.M.; Duran, C.O.; Balasch, M.; Plana-Durán, J.; Domingo, M. Identification of porcine circovirus in tissues of pigs with porcine dermatitis and nephropathy syndrome. Vet. Rec. 2000, 146, 40-43. [CrossRef] [PubMed]

80. Ladekjaer-Mikkelsen, A.S.; Nielsen, J.; Storgaard, T.; Bøtner, A.; Allan, G.; McNeilly, F. Transplacental infection with PCV-2 associated with reproductive failure in a gilt. Vet. Rec. 2001, 148, 759-760. [PubMed]

81. West, K.H.; Bystrom, J.M.; Wojnarowicz, C.; Bøtner, A.; Allan, G.; McNeilly, F. Myocarditis and abortion associated with intrauterine infection of sows with porcine circovirus 2. J. Vet. Diagn. Investig. 1999, 11, 530-532. [CrossRef] [PubMed]

82. Hattermann, K.; Roedner, C.; Schmitt, C.; Finsterbusch, T.; Steinfeldt, T.; Mankertz, A. Infection studies on human cell lines with porcine circovirus type 1 and porcine circovirus type 2. Xenotransplantation 2004, 11, 284-294. [CrossRef] [PubMed]

83. Dubin, G.; Toussaint, J.F.; Cassart, J.P.; Howe, B.; Boyce, D.; Friedland, L.; Abu-Elyazeed, R.; Poncelet, S.; Han, H.H.; Debrus, S. Investigation of a regulatory agency enquiry into potential porcine circovirus type 1 contamination of the human rotavirus vaccine, Rotarix: Approach and outcome. Hum. Vaccin Immunother. 2013, 9, 2398-2408. [CrossRef] [PubMed]

84. Arteaga-Troncoso, G.; Guerra-Infante, F.; Rosales-Montano, L.M.; Diaz-Garcia, F.J.; Flores-Medina, S. Ultrastructural alterations in human blood leukocytes induced by porcine circovirus type 1 infection. Xenotransplantation 2005, 12, 465-472. [CrossRef] [PubMed]

85. Tischer, I.; Bode, L.; Apodaca, J.; Timm, H.; Peters, D.; Rasch, R.; Pociuli, S.; Gerike, E. Presence of antibodies reacting with porcine circovirus in sera of humans, mice, and cattle. Arch. Virol. 1995, 140, 1427-1439. [CrossRef] [PubMed]

86. Victoria, J.G.; Wang, C.; Jones, M.S.; Victoria, J.G.; Wang, C.; Jones, M.S.; Jaing, C.; McLoughlin, K.; Gardner, S.; Delwart, E.L. Viral nucleic acids in live-attenuated vaccines: Detection of minority variants and an adventitious virus. J. Virol. 2010, 84, 6033-6040. [CrossRef] [PubMed]

87. Gilliland, S.M.; Forrest, L.; Carre, H.; Jenkins, A.; Berry, N.; Martin, J.; Minor, P.; Schepelmann, S. Investigation of porcine circovirus contamination in human vaccines. Biologicals 2012, 40, 270-277. [CrossRef] [PubMed]

88. McClenahan, S.D.; Krause, P.R.; Uhlenhaut, C. Molecular and infectivity studies of porcine circovirus in vaccines. Vaccine 2011, 29, 4745-4753. [CrossRef] [PubMed]

89. Ruiz-Palacios, G.M.; Pérez-Schael, I.; Velázquez, F.R.; Abate, H.; Breuer, T.; Clemens, S.C.; Cheuvart, B.; Espinoza, F.; Gillard, P.; Innis, B.L.; et al. Human Rotavirus Vaccine Study Group. Safety and efficacy of an attenuated vaccine against severe rotavirus gastroenteritis. N. Engl. J. Med. 2006, 354, 11-22. [CrossRef] [PubMed] 
90. Vesikari, T.; Clark, H.F.; Offit, P.A.; Dallas, M.J.; DiStefano, D.J.; Goveia, M.G.; Ward, R.L.; Schödel, F.; Karvonen, A.; Drummond, J.E.; et al. Effects of the potency and composition of the multivalent human-bovine (WC3) reassortant rotavirus vaccine on efficacy, safety and immunogenicity in healthy infants. Vaccine 2006, 24, 4821-4829. [CrossRef] [PubMed]

91. Baylis, S.A.; Finsterbusch, T.; Bannert, N.; Blümel, J.; Mankertz, A. Analysis of porcine circovirus type 1 detected in Rotarix vaccine. Vaccine 2011, 29, 690-697. [CrossRef] [PubMed]

92. Paradis, K.; Langford, G.; Long, Z.; Heneine, W.; Sandstrom, P.; Switzer, W.M.; Chapman, L.E.; Lockey, C.; Onions, D. Otto ESearch for cross-species transmission of porcine endogenous retrovirus in patients treated with living pig tissue. The XEN 111 Study Group. Science 1999, 285, 1236-1241. [CrossRef] [PubMed]

93. Matsumoto, S.; Abalovich, A.; Wechsler, C.J.; Wynyard, S.; Elliott, R.B. Clinical Benefit of Islet Xenotransplantation for the Treatment of Type 1. EBio Med. 2016, 12, 255-262. [CrossRef] [PubMed]

94. Wynyard, S.; Nathu, D.; Garkavenko, O.; Denner, J.; Elliott, R.B. Microbiological safety of the first clinical pig islet xenotransplantation trial in New Zealand. Xenotransplantation 2014, 21, 309-323. [CrossRef] [PubMed]

95. Cooper, D.K.; Matsumoto, S.; Abalovich, A.; Itoh, T.; Mourad, N.I.; Gianello, P.R.; Wolf, E.; Cozzi, E. Progress in clinical encapsulated islet xenotransplantation. Transplantation 2016, 100, 2301-2308. [CrossRef] [PubMed]

96. Morozov, A.V.; Wynyard, S.; Matsumoto, S.; Abalovich, A.; Denner, J.; Elliott, R.B. No PERV transmission during a clinical trial of pig islet cell transplantation. Virus Res. 2016, 227, 34-40. [CrossRef] [PubMed]

97. Muzina, M.; Muzina, Z.; Powels, K.; Elliot, R.B.; Croxson, M.C. Monitoring for potentially xenozoonotic virus in New Zealand pigs. J. Med. Virol. 2004, 72, 338-344.

98. Garkavenko, O.; Dieckhoff, B.; Wynyard, S.; Denner, J.; Elliot, R.B.; Tan, P.L.; Croxson, M.C. Absence of transmission of potentially xenotic viruses in a prospective pig to primate islet xenotransplantation study. J. Med. Virol. 2008, 80, 2046-2052. [CrossRef] [PubMed]

99. Jin, S.M.; Shin, J.S.; Kim, K.S.; Gong, C.H.; Park, S.K.; Kim, J.S.; Yeom, S.C.; Hwang, E.S.; Lee, C.T.; Kim, S.J.; et al. Islet isolation from adult designated pathogen-free pigs: Use of the newer bovine nervous tissue-free enzymes and a revised donor selection strategy would improve the islet graft function. Xenotransplantation 2011, 18, 369-379. [CrossRef] [PubMed]

100. Gazda, L.S.; Collins, J.; Lovatt, A.; Holdcraft, R.W.; Morin, M.J.; Galbraith, D.; Graham, M.; Laramore, M.A.; Maclean, C.; Black, J.; et al. A comprehensive microbiological safety approach for agarose encapsulated porcine islets intended for clinical trials. Xenotransplantation 2016, 23, 444-463. [CrossRef] [PubMed]

101. Beach, N.M.; Meng, X.J. Efficacy and future prospects of commercially available and experimental vaccines against porcine circovirus type 2 (PCV2). Virus Res. 2012, 164, 33-42. [CrossRef] [PubMed]

102. Segalés, J. Best practice and future challenges for vaccination against porcine circovirus type 2 . Expert Rev. Vaccines 2015, 14, 473-487. [CrossRef] [PubMed]

103. Madec, F.; Rose, N.; Grasland, B.; Cariolet, R.; Jestin, A. Post-weaning multisystemic wasting syndrome and other PCV2-related problems in pigs: A 12-year experience. Transbound Emerg. Dis. 2008, 55, 273-283. [CrossRef] [PubMed]

104. Glass, F. PCV2 vaccination changing the pig industry. Part 3. Reduced antibiotic usage and improved performance go together. Pig Progr. 2010, 26, 28-30.

105. Fort, M.; Sibila, M.; Allepuz, A.; Mateu, E.; Roerink, F.; Segalés, J. Porcine circovirus type 2 (PCV2) vaccination of conventional pigs prevents viremia against PCV2 isolates of different genotypes and geographic origins. Vaccine 2008, 26, 1063-1071. [CrossRef] [PubMed]

106. Madson, D.M.; Patterson, A.R.; Ramamoorthy, S.; Pal, N.; Meng, X.J.; Opriessnig, T. Effect of porcine circovirus type 2 (PCV2) vaccination of the dam on PCV2 replication in utero. Clin. Vaccine Immunol. 2009, 16, 830-834. [CrossRef] [PubMed]

107. Gerber, P.F.; Garrocho, F.M.; Lana, A.M.Q.; Lobato, Z.I.P. Fetal infections and antibody profiles in pigs naturally infected with porcine circovirus type 2 (PCV2). Can. J. Vet. Res. 2012, 76, 38-44. [PubMed]

108. O’Neill, K.C.; Shen, H.G.; Lin, K.; Hemann, M.; Beach, N.M.; Meng, X.J.; Halbur, PG.; Opriessnig, T. Studies on porcine circovirus type 2 vaccination of 5-day-old piglets. Clin. Vaccine Immunol. 2011, 18, 1865-1871. [CrossRef] [PubMed]

109. Seo, H.W.; Han, K.; Park, C.; Chae, C. Clinical, virological, immunological and pathological evaluation of four porcine circovirus type 2 vaccines. Vet. J. 2014, 200, 65-70. [CrossRef] [PubMed]

110. Afghah, Z.; Webb, B.; Meng, X.J.; Ramamoorthy, S. Ten years of PCV2 vaccines and vaccination: Is eradication a possibility. Vet. Mic. 2016. [CrossRef] [PubMed] 
111. Denner, J. Xenotransplantation and porcine cytomegalovirus (PCMV). Xenotransplantation 2015, 22, 329-335. [CrossRef] [PubMed]

112. Denner, J.; Mueller, N.J. Preventing transfer of infectious agents. Int. J. Surg. 2015, 23, 306-311. [CrossRef] [PubMed]

113. Park, J.S.; Kim, J.; Ha, Y.; Jung, K.; Choi, C.; Lim, J.K.; Kim, S.H.; Chae, C. Birth abnormalities in pregnant sows infected intranasally with porcine circovirus 2. J. Com. Pathol. 2005, 132, 139-144. [CrossRef] [PubMed]

114. Heinze, J.; Plotzki, E.; Denner, J. Virus safety of xenotranplantation: Prevalence of porcine circovirus 2 (PCV2) in pigs. Ann. Virol. Res. 2016, 2, 1023.

115. Schuurman, H.J. Microbiological Denner, J. safety of clinical xenotransplantation products: Monitoring strategies and regulatory aspects. A commentary. Xenotransplantation 2016, 23, 440-443. [CrossRef] [PubMed]

116. Bielanski, A.; Algire, J.; Lalonde, A.; Garceac, A.; Pollard, J.W.; Plante, C. Nontransmission of porcine circovirus 2 (PCV2) by embryo transfer. Theriogenology 2013, 80, 77-83. [CrossRef] [PubMed]

(c) 2017 by the authors. Licensee MDPI, Basel, Switzerland. This article is an open access article distributed under the terms and conditions of the Creative Commons Attribution (CC BY) license (http:/ / creativecommons.org/licenses/by/4.0/). 